\title{
Organic fractions and metal-organic complexes in the groundwater
}

\author{
Ramune Albrektiene, Mindaugas Rimeika, Ruta Grazeniene \\ Vilnius Gediminas Technical University, Sauletekio al. 11, 10223 Vilnius, Lithuania
}

\begin{abstract}
Natural organic matters are widely used in both surface and underground waters, which are prepared as drinking water. The organic matter are divided into four fractions: very hydrophobic acids (VHA), slightly hydrophobic acids (SHA), hydrophilic charged (CHA) and hydrophilic neutral (NEU). Organic matters are negatively charged so they form complexes with metals. For the determination of organic fractions and metal organic complexes rapid fractionation technique is used. Researches were made in Nida and Preila (III group (open)), Taujenai and Petronys (II group (semi-closed)) water well fields. After fractional studies were made it showed that $90 \%$ of all organic compounds composed of very hydrophobic acids (VHA) and slightly hydrophobic acids (SHA) which consist of a large molecular weight compounds. Over $90 \%$ of bivalent iron composed complex compounds with hydrophobic organic matters. Manganese does not entirely complexes with organic compounds.
\end{abstract}

Keywords: ground water; natural organic matters; rapid fractionation.

\section{Introduction}

The concentration of humic acids in Lithuanian underground water is $0.02-0.08 \mathrm{mg} / \mathrm{l}$, sometimes it reaches up to $0.8-$ $1.0 \mathrm{mg} / 1$ [1]. Natural organic compounds can be insoluble, soluble and in colloidal form. A complex heterogeneous mix, which contains humic and fulvic acids, small molecular mass organic acids, carbohydrates, proteins and other classes of compounds, forms natural organic compounds which are both in the groundwater and in the surface-water [2]. Organic compounds are divided into two main classes: non-humus compounds, such as proteins, polysaccharides, nucleic acids, amino acids etc., and humic materials [3]. Humic substances are divided into humic acids, fulvic acids, and humines [4]. 40 to $80 \%$ of soluble and colloidal organic compounds contain humic substances [5], namely humic and fulvic acids. Humic acid, with molecular mass higher than $2000 \mathrm{~g} / \mathrm{mol}$, is usually in the colloidal form and it is a typical sol that precipitates. Humic acids have the polymeric structure which contains benzene cycles, chains and functional groups [6]. Fulvic acids are of lower molecular weight and have a higher oxygen but lower carbon content than humic acids. Fulvic acids contain more acidic functional groups particularly $-\mathrm{COOH}$. Another important difference is that the oxygen in fulvic acids may be mostly contained in known functional groups $(\mathrm{COOH}, \mathrm{OH}, \mathrm{C}=\mathrm{O})[7]$.

It has been found that using the physical and chemical fractionation of organic compounds at different $\mathrm{pH}$ values, organic compounds can be divided to hydrophobic and hydrophilic substances [8]. Table 1 shows the classification of fractions of organic compounds.

Chow with colleagues [13] presented data of the fractionation analysis in which organic compounds are divided into four fractions (very hydrophobic acids (VHA), slightly hydrophobic acids (SHA), hydrophilic charged compounds (CHA) and hydrophilic neutral compounds (NEU)) by using three different resins: DAX-8, XAD-8 and IRA-958. Buchanan with colleagues [14] states that these fractions can be used to determine what functional groups are predominant in a certain fraction; for example aromatic compounds are prevalent in hydrophobic fractions more often than in hydrophilic fractions. Croue [15] states that organic compounds that have bigger molecular mass and more aromatic rings are more hydrophobic. Fraction that is soluble in alkalines, but insoluble in acids is called humic acid [16]. During disinfection organic compounds form secondary substances, such as haloacetatic acid and trihalomethanes [17]. Most of them are pharmacologically active and have cancerogenous properties [18].

Corresponding author: Ramunė Albrektienė. E-mail address: ramune.albrektiene@vgtu.lt

http://dx.doi.org/10.3846/enviro.2014.070

(C) 2014 The Authors. Published by VGTU Press. This is an open-access article distributed under the terms of the Creative Commons Attribution License, which permits unrestricted use, distribution, and reproduction in any medium, provided the original author and source are credited. 
Table 1. Fractions of organic compounds

\begin{tabular}{|c|c|c|c|}
\hline Fractions & & Class of organic compounds & Authors \\
\hline & & Hydrophobic fractions & \\
\hline Hydrophobic acids & & $\begin{array}{l}\text { Fulvic acids, } \mathrm{C}_{5}-\mathrm{C}_{9} \text { aliphatic carboxylic acids, 1- and 2- cycles aromatic } \\
\text { carboxylic acids, } 1 \text { - and } 2 \text { - cycles phenols }\end{array}$ & $\begin{array}{l}\text { Leenheer 1981; Marhaba et al. 2000; } \\
\text { Barber et al. 2001; Aiken et al. } 1992 \\
\text { [9-12] }\end{array}$ \\
\hline \multirow{2}{*}{\multicolumn{2}{|c|}{ Hydrophobic bases }} & $\begin{array}{l}\text { Part of the humic matters stopped by XAD- } 8 \text { resins when } \mathrm{pH} 7,1-\text { and 2- } \\
\text { aromatic cycles compounds except pyridine, protonated compounds }\end{array}$ & $\begin{array}{l}\text { Leenheer 1981; Marhaba et al. 2000; } \\
\text { Barber et al. 2001 [9-11] }\end{array}$ \\
\hline & & Hydrophilic fractions & \\
\hline Hydrophilic acids & & $\begin{array}{l}>\mathrm{C}_{5} \text { aliphatic carboxylic acids, polyfunction carboxylic acids, mix of various } \\
\text { hydroxy acids }\end{array}$ & $\begin{array}{l}\text { Leenheer 1981; Marhaba et al. 2000; } \\
\text { Barber et al. 2001; Aiken et al. } 1992 \\
\text { [9-12] }\end{array}$ \\
\hline $\begin{array}{l}\text { Hydrophilic } \\
\text { compounds }\end{array}$ & neutral & $\begin{array}{l}\text { Short-chain aliphatic amines, alcohols, aldehydes, esters, ketones, }<\mathrm{C}_{5} \\
\text { aliphatic amides, polyfunction alcohols, carbohydrates, cyclic amides, } \\
\text { polysaccharides ( } 55-85 \% \text { determined compounds after pyrolysis were } \\
\text { polysaccharides) }\end{array}$ & $\begin{array}{l}\text { Leenheer 1981; Marhaba et al. 2000; } \\
\text { Barber et al. 2001 [9-11] }\end{array}$ \\
\hline
\end{tabular}

Humic acids have sorption properties therefore they form soluble and insoluble salts, and similarly complex compounds with organic and inorganic substances. Organic compounds are charged negatively, so they compose complexes with metals [19]. Complex compounds with metals are mostly composed by humic acids and these compounds have migration properties. Stability of these complexes depends on the $\mathrm{pH}$ value and ionic strength. Complex compounds form with $\mathrm{Fe}(\mathrm{III})$, $\mathrm{Fe}(\mathrm{II}), \mathrm{Al}(\mathrm{III}), \mathrm{Cu}(\mathrm{II}), \mathrm{Mn}(\mathrm{II}), \mathrm{Ni}(\mathrm{II}), \mathrm{Co}(\mathrm{II}), \mathrm{Pb}(\mathrm{II}), \mathrm{Ca}(\mathrm{II}), \mathrm{Zn}(\mathrm{II})$ and other metal ions [20]. Jobin and Ghosh [21] found, that $\mathrm{Fe}(\mathrm{II})-\mathrm{Fe}$ (III) pairs in the water work like catalysts in oxidation of organic compounds. Hereby reactions of $\mathrm{Fe}(\mathrm{II})$ complexation and $\mathrm{Fe}(\mathrm{III})$ reduction are possible. Theis and Singer [22] proposed a scheme how iron forms complex compounds with organic compounds. Divalent iron reacts with oxygen and quickly turns into trivalent, hydrolysis occurs and insoluble precipitate of trivalent iron forms. If the water has a high concentration of organic compounds, divalent iron coheres with organic compounds. Whether divalent iron will compose complexes with organic compounds or oxidize depends on the water's $\mathrm{pH}$ value and concentration of organic compounds in the water. Complex organic compounds of divalent iron oxidize to the trivalent iron's complex organic compounds quite slowly. These substances are unstable, so divalent iron's organic compounds form again. Divalent iron falls into a circle, where it can compose complex compounds with organic substances or can be oxidized to trivalent iron. Baigorri with partners [23] have found that metals could be connected with humic materials in different bonds:

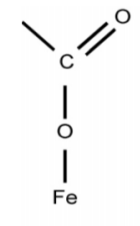

(I)

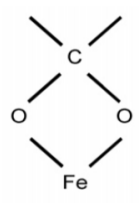

(II)

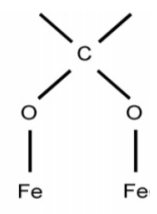

(III)

Fig. 1. Options of chemicals bonds of iron and humic matters (I - monodental, II - bidental, III - bidental bridge)

(Baigorri et al. 2007)

Rahman with colleagues [24] proved that iron usually connects with carboxyl groups. During analysis it was found, that iron's organic complex compound is large and polydispersive with size of hundreds nanometres. Yang with colleagues (2009) found, that complex compounds of metals with humic materials are more stable than complex compounds of metals with fulvic acids. Munter with colleagues [25] published that trivalent iron's complex compounds with humic acids are stronger and more stable in comparison with divalent iron's complex compounds with humic acids.

Nida and Preila water well fields are in Lithuania in Curonian Spit with the Baltic Sea from one side of it and the Curonian Lagoon from the other side. Nida and Preila water well fields belong to the group of open water-places. These water-places exploit open layers of the groundwater. These water well fields belong to IIIb subgroup, because they are close to the surface-water, i.e. the lagoon. Taujenai and Petronys water well fields belong to subgroup of semi-closed water-places in the II group. There are increased concentrations of iron, manganese, ammonium, and organic substances in all four water well field. The usual technologies (aeration and filtration through the granular filtration stuff) are ineffective in elimination of iron, manganese compounds and ammonia ions from groundwater when large concentrations of organic compounds are present. Rapid fractionation technique is used to characterise organic compounds. This technique could be applied in finding organic compounds' complexes with iron and manganese in water. 


\section{Materials and methods}

Samples were taken from Nida, Preila (III group (open)), Taujenai and Petronys (II group (semi-closed)) water well fields. Water quality values are presented in table 2 . The obtained result of analysis is an arithmetical average of concentrations of three aliquots, when disparity was no more $5 \%$. When disparity was higher, concentrations were tested repeatedly.

Table 2. Groundwater quality of Lithuania's well fields

\begin{tabular}{|c|c|c|c|c|c|}
\hline \multirow[t]{2}{*}{ Water quality parameters, dimensions } & \multicolumn{4}{|c|}{ Water quality parameter's value and standard deviation } & \multirow[t]{2}{*}{ HN 24:2003 requirements } \\
\hline & Nida & Preila & Taujenai & Petronys & \\
\hline $\mathrm{pH}, \mathrm{pH}$ units & $7.4 \pm 0.1$ & $7.2 \pm 0.1$ & $7.4 \pm 0.1$ & $7.3 \pm 0.1$ & $6.5-9.5$ \\
\hline Permanganate index, $\mathrm{mgO}_{2} / 1$ & $6.0 \pm 0.3$ & $5.0 \pm 0.6$ & $4.0 \pm 0.2$ & $3.2 \pm 0.2$ & 0,5 \\
\hline $\mathrm{UV}_{254}$ absorption, $1 / \mathrm{m}$ & $0.1 \pm 0.0$ & $0.1 \pm 0.0$ & $0.1 \pm 0.0$ & $0.1 \pm 0.0$ & - \\
\hline Colour, mgPt/1 & $44 \pm 4$ & $54 \pm 6$ & $28 \pm 5$ & $13 \pm 3$ & 30 \\
\hline Total iron, $\mu \mathrm{g} / \mathrm{l}$ & $3170 \pm 54$ & $2976 \pm 163$ & $3998 \pm 60$ & $1592 \pm 27$ & 200 \\
\hline Ammonia, mg/l & $1.4 \pm 0.0$ & $11.4 \pm 0.9$ & $0.5 \pm 0.1$ & $0.6 \pm 0.1$ & 0.5 \\
\hline Manganese, $\mu \mathrm{g} / 1$ & $255 \pm 2$ & $215 \pm 5$ & $60 \pm 2$ & $78 \pm 2$ & 50 \\
\hline
\end{tabular}

201 of water samples were taken and transported to Norwegian Science and Technology University Water Laboratory and to Vilnius Gediminas Technical University Water Management Laboratory. Water samples were kept in refrigeration containers and temperature was below $5{ }^{\circ} \mathrm{C}$.

The fractionation procedure was based on Croue with colleagues [15] and Bolto with colleagues [26] researches for determination of organic fractions using different resins. Four different fractions (very hydrophobic acids, slightly hydrophobic acids, hydrophilic charged acids and hydrophilic neutral acids) can be separated using three different resins.

Fractionation was performed twice for each water sample. Three resins (DAX-8, XAD-8 and IRA-958) were used. Three glass columns $20 \mathrm{~cm}$ in height and $13 \mathrm{~mm}$ in diameter each were filled with $15 \mathrm{~cm}$ of resin. $500 \mathrm{ml}$ of water was filtered through a $0.54 \mu \mathrm{m}$ cellulose nitrate filter. Filtered sample was acidized to $\mathrm{pH} 2.0 \mathrm{using}$ hydrochloric acid. Then sample was filtered through the first column containing DAX-8 resin. Speed of filtration was $3 \mathrm{ml} / \mathrm{min}$. The first $30 \mathrm{ml}$ were discarded. After filtration of sample was completed, $50 \mathrm{ml}$ of water was taken to test the concentration of dissolved organic carbon (DOC). Remaining part of sample was filtered through second column with XAD-8 resin. $\mathrm{pH}$ index value of sample was kept equal to 2.0. The first $30 \mathrm{ml}$ were discarded. After filtration of this sample was completed, $100 \mathrm{ml}$ of water was taken to test the concentration of dissolved organic carbon. Remaining water was alkalized with $\mathrm{NaOH}$ solution until the $\mathrm{pH}$ index value reaches 8.0. Then sample was filtered through third column with IRA-958. The first 30 ml were discarded. After filtration testing of DOC was performed.

Regeneration of resins must be done after the completion of filtration. DAX-8 and XAD-8 was regenerated at first with $60 \mathrm{ml}$ of $0.1 \mathrm{M} \mathrm{NaOH}$ solution, then $60 \mathrm{ml}$ deionized water, $60 \mathrm{ml} 0.1 \mathrm{M} \mathrm{HCl}$ solution and $60 \mathrm{ml}$ deionized water. IRA-958 was regenerated by pumping through the resin $60 \mathrm{ml}$ of $1 \mathrm{M} \mathrm{NaOH} / \mathrm{NaCl}$ solution, $60 \mathrm{ml}$ deionized water, $60 \mathrm{ml} 1 \mathrm{M}$ $\mathrm{HCl} / \mathrm{NaCl}$ solution and $60 \mathrm{ml}$ deionized water. After regeneration, testing of concentration of dissolved organic carbon was performed. Concentration can't exceed $0.2 \mathrm{mg} / \mathrm{l}$. Concentrations of fractions were calculated using formulas:

$$
\begin{aligned}
& \text { VHA }=\text { DOC }(\text { raw water })-\text { DOC }(\text { DAX-8 effluent }) \\
& \text { SHA }=\text { DOC }(\text { DAX-8 effluent })-\text { DOC (XAD-8 effluent }) \\
& \text { CHA }=\text { DOC (XAD-8 effluent })- \text { DOC (IRA-958 effluent); } \\
& \text { NEU }=\text { DOC (IRA-958 effluent) }
\end{aligned}
$$




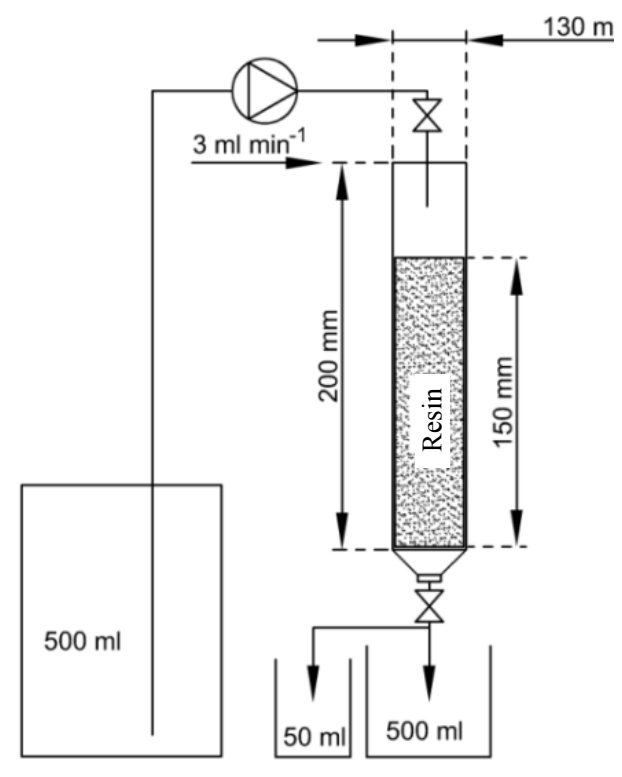

Fig. 2. Layout of fractionation setup

Total organic carbon determination in underground drinking-water is based on standard LST EN 1484:2002. "Water analysis - Guidelines for the determination of total organic carbon (TOC) and dissolved organic carbon (DOC)". Tests were done using analyser Dohrmann Apollo 9000, Teledyne-Temar.

Total iron in water is discovered by adding 1.10-phenanthroline solution to exploratory sample. Orange complex compound forms and its colour intensity is measured using spectrometer Genesys 10VT at $510 \mathrm{~nm}$ wave length (LST ISO 6333:1995).

Concentration of manganese in water is discovered by examination of orange-red complex using spectrometer Genesys 10VT at $450 \mathrm{~nm}$ wave length (LST ISO 6333:1998).

The obtained results of analysis are arithmetical averages of the concentrations of three samples, when disparity was no more $5 \%$. When disparity was higher, concentrations were tested repeatedly.

\section{Results and discussion}

The more organic compounds are found in the water, the more difficult is the removal of iron and manganese compounds. Organic compounds can form complexes with metals; these compounds are difficult to remove using only oxidation. In our case, water of Nida, Preila (III group (open)) and Taujenai, Petronys (II group (semi-closed)) water well fields contains a lot of organic compounds (concentration of total organic carbon in fields was respectively: $9.63 \mathrm{mg} / \mathrm{l}, 5.63 \mathrm{mg} / \mathrm{l}, 4.33 \mathrm{mg} / \mathrm{l} \mathrm{and}$ $3.85 \mathrm{mg} / \mathrm{l})$. It was needed to determinate dominating fractions of organic compounds in groundwater. Concentrations of organic compounds' fractions in groundwater of Nida, Preila (III group (open)) and Taujènai, Petronys (II group (semiclosed)) water well fields are presented in Table 3.

Table 3. Concentrations of organic compounds fractions in groundwater of Lithuania wellfields

\begin{tabular}{|c|c|c|c|c|}
\hline \multirow[t]{2}{*}{ Groundwater quality parameters, dimensions } & \multicolumn{4}{|c|}{ Water quality parameter's value and standard deviation } \\
\hline & Nida & Preila & Taujenai & Petronys \\
\hline Total organic carbon (TOC), mg/l & $9.63 \pm 0.08$ & $5.63 \pm 1.02$ & $4.33 \pm 0.04$ & $3.85 \pm 0.32$ \\
\hline Dissolved organic carbon (DOC), mg/l & $8.07 \pm 0.25$ & $5.07 \pm 0.64$ & $4.06 \pm 0.15$ & $3.27 \pm 0.24$ \\
\hline Dissolved organic carbon after resin DAX-8, mg/l & $2.45 \pm 0.01$ & $1.53 \pm 0.19$ & $1.06 \pm 0.05$ & $0.99 \pm 0.09$ \\
\hline Dissolved organic carbon after resin IRA-958 & $0.31 \pm 0.00$ & $0.37 \pm 0.05$ & $0.22 \pm 0.08$ & $0.17 \pm 0.04$ \\
\hline Fraction of very hydrophobic acids (VHA), mg/l & $5.62 \pm 0.23$ & $3.53 \pm 0.46$ & $3.00 \pm 0.15$ & $2.28 \pm 0.26$ \\
\hline Fraction of slightly hydrophobic acids (SHA), mg/l & $1.44 \pm 0.02$ & $0,890,14$ & $0.60 \pm 0.03$ & $0.64 \pm 0.07$ \\
\hline Fraction of hydrophilic charged compounds (CHA), mg/l & $0.70 \pm 0.04$ & $0.28 \pm 0.09$ & $0.24 \pm 0.04$ & $0.18 \pm 0.05$ \\
\hline Fraction of hydrophilic neutral compounds (NEU), mg/l & $0.31 \pm 0.00$ & $0.37 \pm 0.05$ & $0.22 \pm 0.00$ & $0.17 \pm 0.05$ \\
\hline
\end{tabular}


Results of fractionation of groundwater samples from Nida, Preila, Taujenai and Petronys are presented in figure 3. Fractionation was done for all samples and examination of dissolved organic carbon concentration was performed.
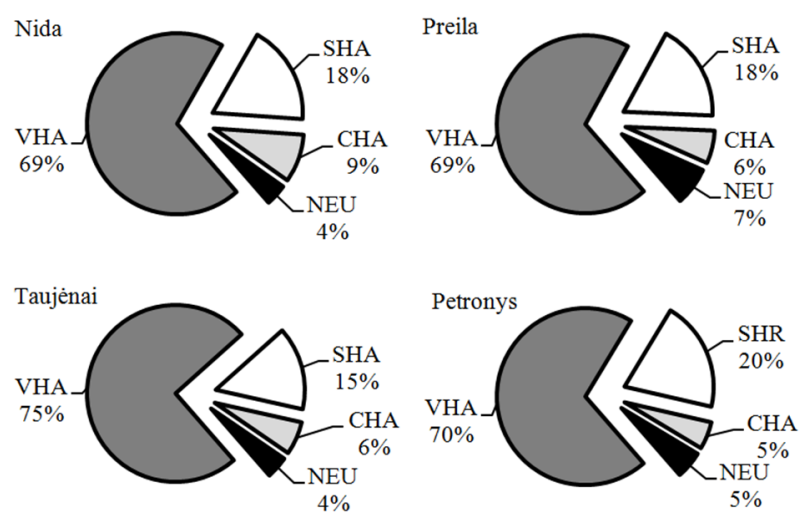

Fig. 3. Fractions of organic compounds in groundwater

From results collected during fractionation examination it is clearly visible that main part of organic compounds in all water fields' groundwater samples is a fraction of VHA (Taujenai - $3.00 \mathrm{mg} / \mathrm{l}$ (75\%), Nida - 5.62 mg/l (69\%), Petronys $2.28 \mathrm{mg} / \mathrm{l}(70 \%)$ and Preila $-3.53 \mathrm{mg} / \mathrm{l}(69 \%))$. It means that fulvic and humic acids are dominating in the groundwater. Those are high-molecular hydrophobic humic compounds that are easily removed by coagulation. Buchanan with colleagues (2005) state that aromatic compounds in hydrophobic fractions are prevalent more often than in hydrophilic fractions. Croue [15] states that organic compounds with higher molecular mass and more aromatic cycles are more hydrophobic. Concentration of SHA is considerably lower comparing with the fraction of VHA. Fraction of SHA in analysed water samples reach $15-20 \%$ of all dissolved organic compounds. This fraction also consists of organic compounds containing higher molecular mass and more aromatic cycles. It means that this fraction of organic compounds is easily removable by coagulation process.

CHA compounds in analysed water samples reach 5-9\% of all dissolved organic compounds. The smallest part of organic matters is a NEU (4-7\%). These fractions consist of short chains aliphatic amines, alcohols, ketones and esters. According to Chow and colleagues [13] the removal of these organic compounds is complicated using coagulation process, because these compounds have a small molecular mass and are hydrophilic. These matters tend to form disinfection byproducts.

After fractionation analysis, it was found that $90 \%$ of all organic matters were composed of VHA and SHA, and these fractions contain large molecular mass compounds. These compounds are effectively removable by coagulation method. And this technique of removal of organic matters is applicable to all discussed water well fields.

Humic acids have sorption properties, and as a result can easily form soluble and insoluble salts, and also complexes with organic and inorganic compounds (Beckett and Le 1990). Organic compounds, specifically fulvic and humic acids, disturb removal of iron from groundwater. Concentration of humic acids in Lithuanian groundwater reaches $0.02-0.08 \mathrm{mg} / \mathrm{l}$, and sometimes up to $0.8-1.0 \mathrm{mg} / 1$ [1]. To discover how much iron is in organic compounds following procedures were performed. Water from all four water well fields was fractionated to separate different organic compound's fractions and then analysis of concentrations of iron and manganese was performed in every fraction. Before fractionation, water was aerated for $24 \mathrm{~h}$, and then filtered through a $0.45 \mu \mathrm{m}$ size pores filter. Concentrations of iron and manganese were analysed in raw water, filtered water and in each fraction. According to Jobin and Ghosh [21], ions of divalent iron form complexes with organic matters and divalent iron compounds are soluble in water, so after filtration only divalent iron remains in the water. Information presented in tables 4 and 5 indicates that groundwater from all water well fields contains divalent iron and manganese compounds in concentrations exceeding allowable values, described in standard HN 24:2003. In the total amount of iron, dissolved iron constitutes 13 to $61 \%$. During aeration divalent iron should be oxidised to insoluble compounds of trivalent iron which can be removed by filtering. From results of the analysis we can make a conclusion that all divalent iron is in complexes with organic compounds.

The results in table 4 suggest that the major part of divalent iron forms complexes with VHA (Nida $-81 \%$, Preila - 86\%, Taujenai $-79 \%$, Petronys $-89 \%$ ). 6 to $18 \%$ of divalent iron forms complex compounds with SHA. These results demonstrate that more than $90 \%$ of divalent iron composes complex compounds with hydrophobic high-molecular organic matters. It means that complex organic compounds with iron can be eliminated using coagulation process.

The results in table 5 suggest that concentrations of organic complex compounds with manganese in both hydrophobic and hydrophilic acids' fractions are very low. Manganese completely does not form complexes with organic compounds. All compounds of manganese are soluble, so chemical or biological methods are needed to remove them from water. 
Table 4. Concentrations of iron in different fractions of organic compounds

\begin{tabular}{lcccc}
\hline & \multicolumn{4}{c}{ Concentration of iron and standard deviation, $\mu \mathrm{g} / \mathrm{l}$} \\
\cline { 2 - 5 } & Nida & Preila & Taujenai & Petronys \\
\hline Total iron & $3170 \pm 54$ & $2976 \pm 163$ & $3998 \pm 60$ & $228 \pm 33$ \\
Dissolved iron & $970 \pm 23$ & $850 \pm 52$ & $236 \pm 15$ & $202 \pm 24$ \\
In VHA fraction & $786 \pm 14$ & $731 \pm 26$ & $186 \pm 23$ & $11 \pm 6$ \\
In SHA fraction & $165 \pm 9$ & $102 \pm 9$ & $32 \pm 12$ & $9 \pm 2$ \\
In CHA fraction & $10 \pm 3$ & $12 \pm 1$ & $9 \pm 3$ & $6 \pm 0$ \\
Fraction & $9 \pm 3$ & $5 \pm 2$ & $9 \pm 2$ & \\
\hline
\end{tabular}

Table 5. Concentrations of manganese in different fractions of organic compounds

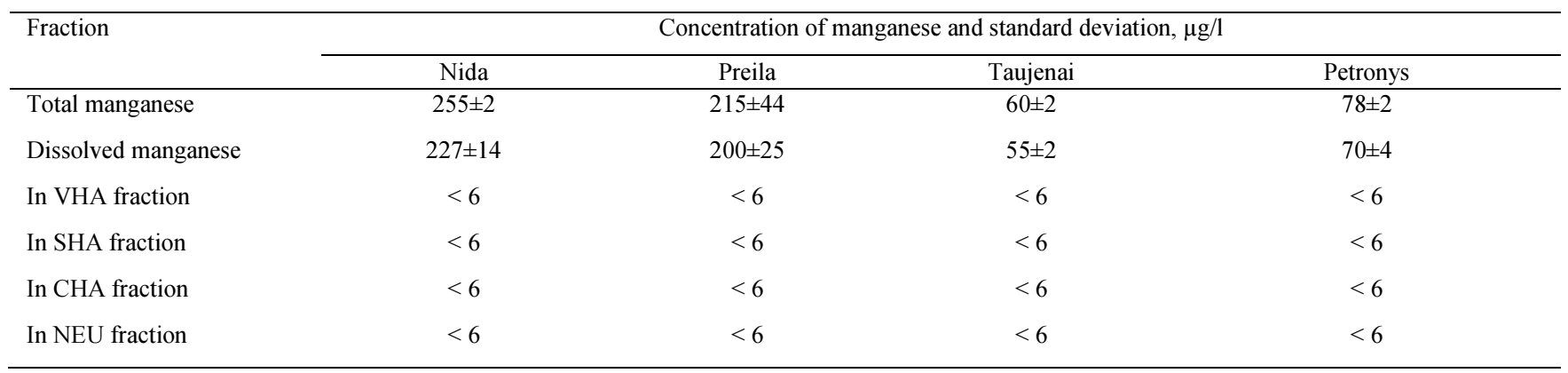

\section{Conclusions}

After analysis of groundwater samples from III group (open) and II group (semi-closed) water well fields fractionation's results it was discovered, that biggest part of organic compounds is the fraction of very hydrophobic acids (Taujenai - 75\%, Nida $-69 \%$, Petronys $-70 \%$ and Preila $-69 \%$ ). After determination of iron and manganese concentration in fractions of organic compounds it was found that major part of soluble divalent iron forms complex compounds with very hydrophobic acids (Nida $-81 \%$, Preila $-86 \%$, Taujenai $-79 \%$, Petronys $-89 \%$ ). Manganese doesn't form complex compounds with any fraction of organic matters.

\section{Acknowledgements}

The authors thank Ltd "Neringa water" and collective of Norwegian University Science and Technology Department of Hydraulic and Environmental Engineering for contribution and opportunity to carry out this work.

\section{References}

[1] Diliūnas, J.; Jurevičius, A.; Zuzevičius, A. 2006. Formation of iron compounds in the Quaternary groundwater of Lithuania, Geologija 55: 66-73.

[2] Her, N.; Amy, G.; McKnight, D.; Sohn, J.; Yoon, Y. 2003. Characterization of DOM as a function of MW by fluorescence EEM and HPLC-SEC using UVA, DOC and Fluorescence detection, Water research 37: 4295-4303. http://dx.doi.org/10.1016/S0043-1354(03)00317-8

[3] Fabris, R.; Chow, Ch. W. K.; Drikas, M.; Eikebrokk, B. 2008. Comarison of NOM character in selected Australian and Norwegian drinking waters, Water research 42(2008): 4188-4196. http://dx.doi.org/10.1016/j.watres.2008.06.023

[4] Donisa, C.; Mocanu, R.; Steinnes, E. 2003. Distribution of some major and minor elements between fulvic and humic acid fractions in natural soils, Geoderma 111: 75-84. http://dx.doi.org/10.1016/S0016-7061(02)00254-9

[5] Muller, M. B.; Fritz, W.; Lankes, U.; Frimel, F. H. 2004. Ultrafiltration of nonionic surfactants and dissolved organic matter, Environmental Science \& Technology 2004(38): 1124-1132. http://dx.doi.org/10.1021/es0300416

[6] Fuentes, M; Baigorri, R.; A. M.; Gonzales-Gaitano, G.; Garcia-Mina, J. M. 2007. The complementary use of 1H NMR, 13C NMR, FTIR and size exclusion chromatography to investigate the principal structural changes associated with composting of organic materials with diverse origin, Organic Geochemistry 38(2007): 2012-2023. http://dx.doi.org/10.1016/j.orggeochem.2007.08.007

[7] Pena-Mendez, E. M.; Havel, J.; Patočka, J. 2005. Humic substances compounds of still unknown structure: applications in agriculture, industry, environment, and biomedicine, Journal of applied biomedicine 3: 13-24.

[8] Leenheer, J. A. 2004. Comprehensive assessment of precursors, diagenesis, and reactivity to water treatment of dissolved and coloidal organic matter, Water Science and Technology: Water Supply 4(4): 1-9.

[9] Leenheer, J. A. 1981. Comprehensive approach to preparative isolation and fractionation of dissolved organic carbon from natural waters and wastewaters, Environmental Science \& Technology 15(5): 578-587. http://dx.doi.org/10.1021/es00087a010

[10] Marhaba, T. F.; Van, D.; Lippincott, R. L. 2000. Changes in NOM fractions through treatment: acomparison of ozonation and chlorination, Ozone Science Engineering 22: 249-266. http://dx.doi.org/10.1080/01919510008547209 
[11] Barber, L. B.; Leenheer, J. A.; Noyes, T. I.; Styles, E. A. 2001. Nature and transformation of dissolved organic matter in treatment wetlands, Environmental Science \&Technology 35: 4805-4816. http://dx.doi.org/10.1021/es010518i

[12] Aiken, G. R.; McKnight, D. M.; Thorn, K. A.; Thurman, E. M. 1992. Isolation of hidrophilic organic acids from water using nonionic macroporous resins, Organic Geochemistry 18(4): 567-573. http://dx.doi.org/10.1016/0146-6380(92)90119-I

[13] Chow, Ch. W. K.; Farbis, R.; Drikas, M. 2004. A rapid fractionation technique to characterise natural organic matter for the optimisation or water treatment processes, Journal of WaterSupply: Research and Technology - Aqua 53(2): 85-92.

[14] Buchanan, W.; Roddick, F.; Porter, N.; Drikas, M. 2005. Fractionation of UV and VUV Pretreated natural organic matter from drinking water, Environmental Science and technology 39 (12): 4647-4654. http://dx.doi.org/10.1021/es048489+

[15] Croue, J. P. 1999. Isolation, fractionationcharacterisation and reactive properties of natural organic matters, in Prosseedings of AWWA18th Federal Conference; Adelaide, Australia, 12-14 April, 1999.

[16] Koopal, L. K.; Reimsdijk, W. H.; Kinniburgh, D. G. 2001. Humic matter and contaminants. General aspects and modeling metal ion binding, Pure and Applied Chemistry 73(12): 2005-2016. http://dx.doi.org/10.1351/pac200173122005

[17] Musikavong, C.; Wattanachira, S.; Marhaba, T. F.; Pavasant, P. 2005. Reduction of organic matter and trihalomethane formation potential in reclaimed water from treated industrial estate wastewater, Journal of Hazardous Material B127: 48-57. http://dx.doi.org/10.1016/j.jhazmat.2005.06.042

[18] Krasner, S. W.; Weinberg, H. S.; Richardson, S. D.; Pastor, S. J.; Chinn, R.; Sclimenti, M .J.; Onstad, G. D.; Thruston, A. D. 2006. Occurrence of a new generation of disinfection byproducts, Environmental Science \& Technology 40(23): 7175-7185. http://dx.doi.org/10.1021/es060353j

[19] Beckett, R.; Le, N. P. 1990. The role of organic matter and ionic composition in determining the surface of suspended particle in natural water, Colloids and Surfaces 4: 35-49. http://dx.doi.org/10.1016/0166-6622(90)80185-7

[20] Calace, N.; Liberatori, A.; Petronio, B. M.; Pietroletti, M. 2001. Organic matters. Environmental Pollution 113(2001): 33.

[21] Jobin, R.; Ghosh, M. M. 1972. Effect of buffer intensity and organic matter on the oxygenation of ferrous iron, Journal AWWA. 64(9): 590-595.

[22] Theis, T. L; Singer, P. C. 1974. Complexation of iron (III) by organic matter and its effect on iron (III) oxygenation, Environmental Science and Technology 8(6): 569-573. http://dx.doi.org/10.1021/es60091a008

[23] Baigorri, R.; Garcia-Mina, J. M.; Gonzalez-Gaitano, G. 2007. Supramolecular association induced by Fe(III) in low molecular weight sodium polyacrylate, Colloids and Surfaces A: Physicochem. Eng. Aspects. 292(2007): 212-216. http://dx.doi.org/10.1016/j.colsurfa.2006.06.027

[24] Rahman, M. A.; Hasan, M. A.; Rahim, A.; Shafigul Alam, A. M. 2010. Characterization of humic acid from the river bottom sediments of Burigonga: Complexation studies of metals with humic acid, Pakistan Journal of Analytical and Environmental Chemistry 11(1): 42-52.

[25] Munter, R.; Ojeaste, H.; Sutt, J. 2005. Complexed iron removal from groundwater, Journal of Environmental Engineering 7(1): 1014-1020. http://dx.doi.org/10.1061/(ASCE)0733-9372(2005)131:7(1014)

[26] Bolto, B.; Abbt-Braum, G.; Dixon, D.; Eldridge, R.; Frimmel, F.; Hesse, S.; King, S; Toifl, M. 1999. Experimental evaluation of cationic polyelectrolytes for removing natural organic matter from water, Water Science and Technology 40(9): 71-79. http://dx. doi.org/10.1016/S02731223(99)00642-3 